\title{
Effect of ciliary neurotrophic factor (CNTF) on motoneuron survival
}

\author{
MICHAEL SENDTNER, YOSHIHIRO ARAKAWA, KURT A. STÖCKLI, GEORG W. KREUTZBERG and
} HANS THOENEN

Max-Planck Institute for Psychiatry, Am Klopferspitz 18a, W-8033 Planegg-Martinsried, Germany

\section{Summary}

We have demonstrated that the extensive degeneration of motoneurons in the rat facial nucleus after transection of the facial nerve in newborn rats can be prevented by local ciliary neurotrophic factor (CNTF) administration. CNTF differs distinctly from known neurotrophic molecules such as NGF, BDNF and NT-3 in both its molecular characteristics (CNTF is a cytosolic rather than a secretory molecule) and its broad spectrum of biological activities. CNTF is expressed selectively by Schwann cells and astrocytes of the peripheral and central nervous system, respectively, but not by target tissues of the great variety of CNTF-responsive neurons. CNTF mRNA is not detectable by Northern blot or PCR analysis during embryonic development and immediately after birth. However, during the second post-natal week, a more than 30-fold increase in CNTF mRNA and protein occurs in the sciatic nerve. Since the period of low CNTF levels in peripheral nerves coincides with that of high vulnerability of motoneurons (i.e. axonal lesion results in degeneration of motoneuron cell bodies), insufficient availability of CNTF may be the reason for the rate of lesioninduced cell death of early post-natal motoneurons. Highly enriched embryonic chick motoneurons in culture are supported at survival rates higher than $60 \%$ by CNTF, even in single cell cultures, indicating that CNTF acts directly on motoneurons. In contrast to CNTF, the members of the neurotrophin gene family (NGF, BDNF and NT-3) do not support the survival of motoneurons in culture. However, aFGF and bFGF show distinct survival activities which are additive to those of CNTF, resulting in the survival of virtually all motoneurons cultured in the presence of CNTF and bFGF.

Key words: motoneurons, ciliary neurotrophic factor, CNTF, nerve lesion, rat, chick, neurotrophic factor.

\section{Introduction}

Survival of spinal motoneurons during the embryonic period of naturally occurring cell death has been shown to depend on the presence of the targets of these neurons, i.e. the skeletal muscle cells (Holliday and Hamburger, 1975; Oppenheim, 1989). Similarly, ciliary neurons, which innervate smooth and striated muscle within the eye (Pilar et al. 1980) die after removal of the eye during early development (Landmesser and Pilar, 1974). Ciliary neurotrophic factor (CNTF) was first identified and partially

Journal of Cell Science, Supplement 15, 103-109 (1991)

Printed in Great Britain (C) The Company of Biologists Limited 1991 purified from late embryonic chick eye tissue (Barbin et al. 1984). The adult rat sciatic nerve was subsequently identified as the most abundant source of CNTF (Manthorpe et al. 1986) wherefrom it was purified to homogeneity as a basis for microsequencing and finally molecular cloning (Stöckli et al. 1989, 1991). In contrast to nerve growth factor (NGF) and other members of the NGF-gene family, i.e. brain-derived neurotrophic factor (BDNF) and neurotrophin-3 (NT-3), CNTF supports the survival of both cultured ciliary neurons from eight day old chick embryos (Barbin et al. 1984) and purified spinal motoneurons from six day old chick embryos (Arakawa et al. 1990). Moreover, it has recently been shown that CNTF supports the survival of spinal motoneurons in vivo when applied daily onto the chorioallantoic membrane of chick embryos from E6 to E9 (Oppenheim et al. 1991), a time-period during which natural cell death of motoneurons occurs. The analysis of CNTF expression during embryonic development (Stöckli et al. 1991) and the perinatal period (Stöckli et al. 1989) suggests that it is highly unlikely that CNTF regulates the survival of neurons during the period of regulated physiological motoneuron death: CNTF mRNA is not expressed by embryonic or adult skeletal muscle cells or any other target tissues of CNTF responsive neurons (Stöckli et al. 1991). Moreover, the expression of CNTF by rat peripheral nerve Schwann cells does not start before postnatal day four, and the high levels found in adult animals are not reached before postnatal week three. During the early postnatal period, lesion of peripheral nerves leads to degeneration of the corresponding motoneurons. We have therefore investigated whether the low levels of CNTF expressed during that time period might be responsible for these high rates of lesion-mediated motoneuron death. Indeed, CNTF application to the proximal stump of lesioned facial nerves in newborn rats rescued virtually all of the axotomized motoneurons (Sendtner et al. 1990). These data indicate that CNTF might act as a 'lesion factor' in postnatal animals rather than a target-derived neurotrophic factor regulating the survival of ciliary and/or motoneurons during embryonic development.

\section{CNTF supports the survival of a great variety of embryonic chick neurons in culture}

CNTF differs significantly from target-derived neurotrophic factors such as NGF, BDNF and NT-3, by the great variety of different neurons whose survival CNTF can support in culture. These neurons include NGF-sensitive chick E10 sympathetic neurons and sensory neurons, but also NGF-insensitive E8 ciliary neurons or neurons from 
Table 1. Survival effect of CNTF on different populations of chick and mammalian neurons in vitro

\begin{tabular}{|c|c|c|c|}
\hline Cell type & $\begin{array}{l}\text { Developmental } \\
\text { stage }\end{array}$ & $\begin{array}{l}\text { Survival } \\
\text { rate }(\%)\end{array}$ & $\begin{array}{l}\text { Days in } \\
\text { culture }\end{array}$ \\
\hline $\begin{array}{l}\text { Chick } \\
\text { ciliary neurons }^{1}\end{array}$ & E8 & 94.5 & 2 \\
\hline $\begin{array}{l}\text { paravertebral }^{1} \\
\text { sympathetic neurons }\end{array}$ & E10 & 87.2 & 3 \\
\hline $\begin{array}{l}\text { dorsal root }{ }^{1} \\
\text { sensory neurons }\end{array}$ & $\begin{array}{l}\text { E8 } \\
\text { E9 } \\
\text { E10 }\end{array}$ & $\begin{array}{r}6.4 \\
21.4 \\
45.4\end{array}$ & $\begin{array}{l}2 \\
2 \\
3\end{array}$ \\
\hline nodose neurons ${ }^{2}$ & E8 & 42.7 & 2 \\
\hline $\begin{array}{l}\text { spinal motoneurons }{ }^{3} \\
\text { spinal motoneurons }\end{array}$ & $\begin{array}{l}\text { E6 } \\
\text { E4 }\end{array}$ & $\begin{array}{c}60.7 \\
\text { no effect }\end{array}$ & $\begin{array}{l}3 \\
3\end{array}$ \\
\hline $\begin{array}{l}\text { trigeminal } \\
\text { ventrolateral neurons }\end{array}$ & E10 & 63.5 & 2 \\
\hline $\begin{array}{l}\text { trigeminal } \\
\text { dorsomedial neurons }{ }^{5}\end{array}$ & E10 & 35.0 & 2 \\
\hline $\begin{array}{l}\text { trigeminal } \\
\text { tractus mesencephalic } \\
\text { neurons }^{5}\end{array}$ & E10 & 61.5 & 2 \\
\hline $\begin{array}{l}\text { Newborn rat } \\
\text { superior cervical } \\
\text { ganglion sympathetic } \\
\text { neurons }\end{array}$ & P0 & $\begin{array}{r}41 \\
9\end{array}$ & $\begin{array}{l}2 \\
7\end{array}$ \\
\hline $\begin{array}{l}\text { Newborn mouse } \\
\text { nodose neurons }^{7}\end{array}$ & P0 & no effect & \\
\hline \multicolumn{4}{|c|}{$\begin{array}{l}{ }^{1} \text { M. Sendtner, unpublished results. } \\
{ }^{2} \text { Y.-A. Barde, personal communication. } \\
{ }^{3} \text { Arakawa et al. (1990). } \\
{ }^{4} \text { Bloch-Gallego et al. (1991). } \\
{ }^{5} \text { A. M. Davies, personal communication. } \\
{ }^{6} \text { Saadat et al. (1989). } \\
{ }^{7} \text { Manthorpe et al. } \text { (1986). }\end{array}$} \\
\hline
\end{tabular}

E8 nodose ganglia, which have been reported to survive in the presence of BDNF and NT-3 (Barde 1989; Hohn et al. 1990) (Table 1). More than $40 \%$ of E8 nodose neurons survive in culture in the presence of CNTF purified from rat sciatic nerve (Table 1). Other neurons derived from the ectodermal placode, i.e. the ventrolateral trigeminal neurons and the proprioceptive neurons of the mesencephalic trigeminal nucleus (Davies and Lindsay, 1985), also show a marked survival response to CNTF (Table 1). The survival effect of CNTF on chick dorsal root sensory neurons is restricted to the time period after E8 (Barbin et al. 1984). However, there are also species differences, i.e. CNTF does not support the survival of newborn rat superior cervical ganglion sympathetic neurons in culture, although these cells do respond to CNTF. However, this response consists of enhanced choline acetyltransferase and reduced tyrosine hydroxylase activity (Saadat et al. 1989). Similarly, in contrast to chick (Table 1), cultured nodose neurons from newborn mice have been reported to be unresponsive to CNTF (Barbin et al. 1984). We have recently reported an improved culture method for highly enriched E6 chick spinal motoneurons (Arakawa et al. 1990). Under the culture conditions reported, CNTF supported the survival of more than $60 \%$ of the initially plated motoneurons for time periods longer than one week. Other neurotrophic factors such as NGF, BDNF and NT-3, had no survival effect even at concentrations up to $10 \mu \mathrm{g} \mathrm{ml}^{-1}$ for NGF and BDNF. However, bFGF supported $51 \%$ and aFGF (in the presence of heparin) $35 \%$ of the initially plated motoneurons. The survival effect of bFGF
Fig. 1. CNTF immunoreactivity in sections of adult rat sciatic nerve and iris. The methods used here are described in detail elsewhere (Stöckli et al. 1991). a), b) transverse sections of rat sciatic nerve; and c), d) longitudinal sections. e), f) transverse section of the central part of the iris which forms the pupil; and $\mathrm{g}$ ), h) transverse section of the lateral part of the iris up to the ciliary body. a), e) and g) phase contrast; in b), c), f) and h) corresponding CNTF-immunofluorescence picture. A control with pre-adsorption of the anti-CNTF antiserum to excess CNTF peptide is shown in d). Bars, $25 \mu \mathrm{m}$.

and CNTF was additive, resulting in a $100 \%$ survival of the initially plated motoneurons over a period of one week. Of a great variety of additional factors tested, only IGF-I and IGF-II showed a small survival activity on chick motoneurons, that was about $10 \%$ above that of the survival of the control cultures $(5 \%)$ in the absence of specific survival factors.

\section{CNTF-immunoreactivity is confined to Schwann cells of peripheral nerves}

Northern blot analysis of CNTF expression in tissues of the adult rat has shown that significant amounts of CNTF mRNA are only detectable in rat peripheral nerves, but not in target tissues of responsive neurons such as skeletal muscle or skin (Stöckli et al. 1989, 1991). Thus, the large quantities of CNTF protein present in the sciatic nerves of adult rat (Williams et al. 1984), rabbit (Lin et al. 1989) and chick (Eckenstein et al. 1990) do not originate from target tissues by retrograde transport, as is the case for NGF (Heumann et al. 1987), but are synthesized locally within the peripheral nerves.

In sections of adult rat sciatic nerves, CNTF immunoreactivity is detectable exclusively in Schwann cells (Fig. 1a-c). It is homogenously distributed within the cytoplasm. Other cellular structures (such as myelin or the nucleus) and other cells (such as fibroblasts) are not stained. In the adult rat eye, CNTF immunoreactivity is exclusively localized in Schwann cells associated with nerve fibres (Fig. 1g, h). No immunoreactivity is detectable in other cells, in particular the constrictor muscle of the iris (Fig. 1e-f), which is a target of the cholinergic ciliary neurons. These observations, together with our recent demonstration that CNTF mRNA is not found in skeletal muscle or skin (Stöckli et al. 1989), clearly indicate that CNTF is neither a target-derived neurotrophic factor for ciliary neurons, nor for other neuronal populations such as dorsal root sensory or spinal motoneurons, even though these cell populations survive in vitro in the presence of this factor.

\section{CNTF prevents the cell death of motoneurons after lesion in postnatal rats}

Natural cell death of rat lumbar motoneurons has been shown to occur between E15 and postnatal day one (Oppenheim, 1986). However, CNTF mRNA cannot be detected in rat E18 hindlimbs by Northern blot analysis of total RNA. Moreover, even by a highly sensitive PCRbased detection method, no signal for CNTF mRNA is detectable in the same tissue (Stöckli et al. 1991). Therefore, CNTF is unlikely to support the survival of 


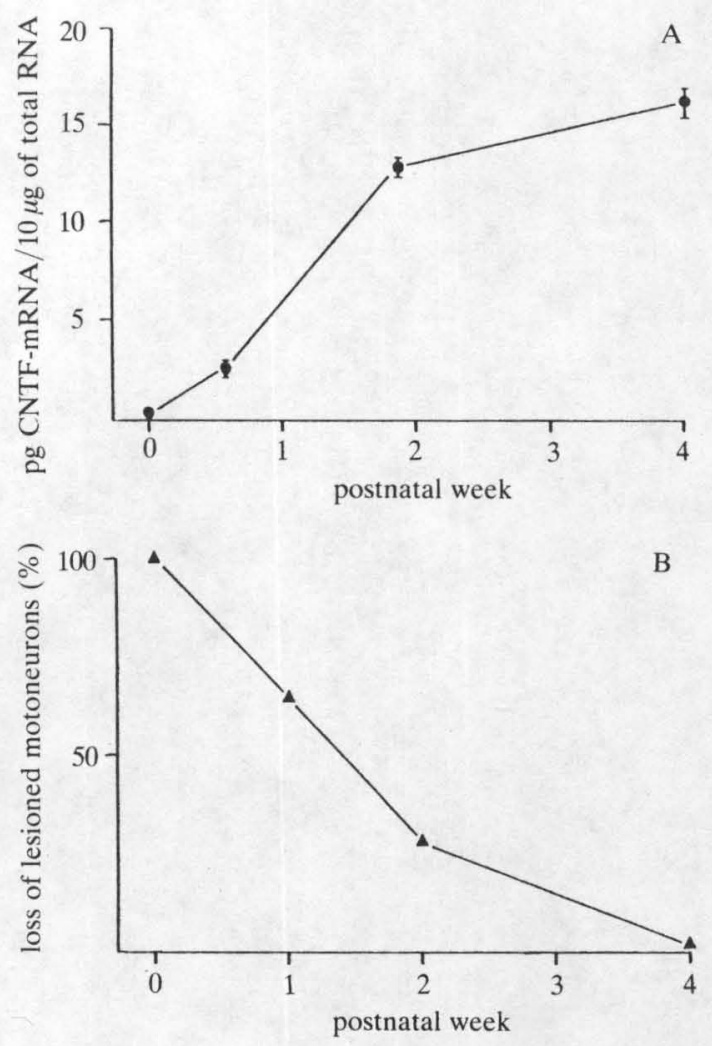

Fig. 2. a) Developmental time-course of CNTF mRNA expression in rat sciatic nerve (data derived from Stöckli et al. 1989). b) Timecourse of the rate of motoneuron cell death after transection of adult rat sciatic nerve (adapted from $\mathrm{H}$. Schmalbruch, 1984).

spinal motoneurons during this critical period of naturally occurring cell death. However, the period of physiological cell death for motoneurons is followed postnatally by a period of high vulnerability to axonal lesion: axotomy of spinal and facial motoneurons in newborn rats leads to complete loss of the injured motoneurons within a few days (Schmalbruch, 1984; Sendtner et al. 1990). This high vulnerability of rat motoneurons steadily decreases during the course of the first four weeks after birth, whereas CNTF expression in Schwann cells of peripheral nerves increases during this period (Fig. $2 \mathrm{a}, \mathrm{b}$ ).

We have investigated whether the low levels of CNTF expression during the first postnatal week in newborn rats are responsible for the extensive neuronal cell death after transection of the facial nerve. This nerve was chosen because the cell bodies of the lesioned motoneurons can be easily identified by their anatomical position within the facial nucleus of the ipsilateral brain stem. As shown in Table 2, we have reported that about $70 \%$ of the lesioned motoneurons can be rescued by application of $5 \mu \mathrm{g}$ of CNTF (purified from rat sciatic nerve) to the proximal stump of the cut facial nerve (Sendtner et al. 1990). Using higher amounts $(8 \mu \mathrm{g})$ of recombinant rat CNTF (supplied by N. Panayotatos, Regeneron Pharmaceuticals, Tarrytown, N.Y.), the number of rescued facial neurons reaches virtually $100 \%$. This indicates that all lesioned motoneurons respond to $\mathrm{CNTF}$.

From these data we conclude that CNTF supports the survival of adult motoneurons under pathophysiological conditions, rather than embryonic motoneurons during the period of naturally occurring cell death before birth.
Table 2. Motoneuron survival after lesion of the facial nerve in newborn rats

\begin{tabular}{lcc}
\hline & \multicolumn{2}{c}{ Number of surviving neurons \pm S.E.M. } \\
\cline { 2 - 3 } & Side with lesion & Side without lesion \\
\hline Untreated animals $(n=1)$ & 685 & 2985 \\
$\begin{array}{l}\text { Animals treated with } \\
\text { BSA gel foam ( } n=3 \text { ) }\end{array}$ & $620 \pm 98$ & $3271 \pm 61$ \\
$\begin{array}{l}\text { Animals treated with gel } \\
\text { foam containing } 5 \mu \mathrm{g} \\
\text { of purified rat sciatic } \\
\text { nerve CNTF ( } n=4)\end{array}$ & $2503 \pm 487$ & $3281 \pm 112$ \\
$\begin{array}{l}\text { Animals treated with gel } \\
\text { foam containing } 8 \mu \mathrm{g} \\
\text { of recombinant } \\
\text { rat CNTF ( } n=2)\end{array}$ & $3830 \pm 465$ & $3920 \pm 385$ \\
\multicolumn{1}{l}{$\begin{array}{l}\text { Methods used and part of the data presented here have already been } \\
\text { published by Sendtner } \text { et al. (1990). Recombinant rat CNTF was a gift of }\end{array}$} \\
N. Panayotatos, Regeneron Pharmaceutical, Tarrytown, N.Y.
\end{tabular}

\section{CNTF supports the survival of E6 chick spinal motoneurons in single cell cultures}

So far nothing is known about the expression of CNTF mRNA and protein in tissues of the developing chick embryo. Although rat and rabbit CNTFs are highly homologous (Stöckli et al. 1989; Lin et al. 1989) and human CNTF could be cloned based on the sequence information available from these two species (Masiakowski et al. 1991), chick CNTF has not yet been cloned. Partial amino acid sequence information published by Eckenstein et al. (1990) showed an astonishingly low similarity to the corresponding sequences of rat and rabbit CNTF. This observation is in agreement with our own, i.e. no signal could be detected in Northern blots from chick tissues, including sciatic nerve (which contains high CNTF-like biological activity), using rat CNTF cDNA probes under low stringency hybridization conditions (C. Saldern, unpublished results). Therefore it is not yet known whether CNTF is expressed in the chick embryo during the time periods of physiological cell death of the great variety of chick neurons responsive to CNTF in vitro (Table 1), and accordingly, whether it would also be of physiological relevance for their survival during that time period.

We have recently described an improved method for culturing E6 chick spinal motoneurons, that allowed the survival of virtually $100 \%$ of the plated neurons under appropriate culture conditions (Arakawa et al. 1990). At least $80 \%$ of the plated cells were shown to be motoneurons; non-neuronal cells, i.e. fibroblasts or immature astrocytes, were virtually absent. It has been reported (Bloch-Gallego et al. 1991) that spinal motoneurons from E4 chick embryos, which had been enriched by a panning procedure using the SC1 monoclonal antibody (Tanaka and Obata, 1984), do not respond to purified chick eye CNTF. This discrepancy with our own findings could be due to the following reasons. 1) The motoneurons were prepared from chick embryos of different developmental stages (E6: Arakawa et al. 1990; E4: Bloch-Gallego et al. 1991). It could well be that E4 motoneurons are not yet responsive to CNTF. 2) We have used purified recombinant rat CNTF for our studies, which does not bind to heparin. Bloch-Gallego et al. (1991) have used CNTF purified from embryonic chick eyes using HeparinSepharose chromatography. This could mean that aFGF was used erroneously in their studies rather than CNTF. 

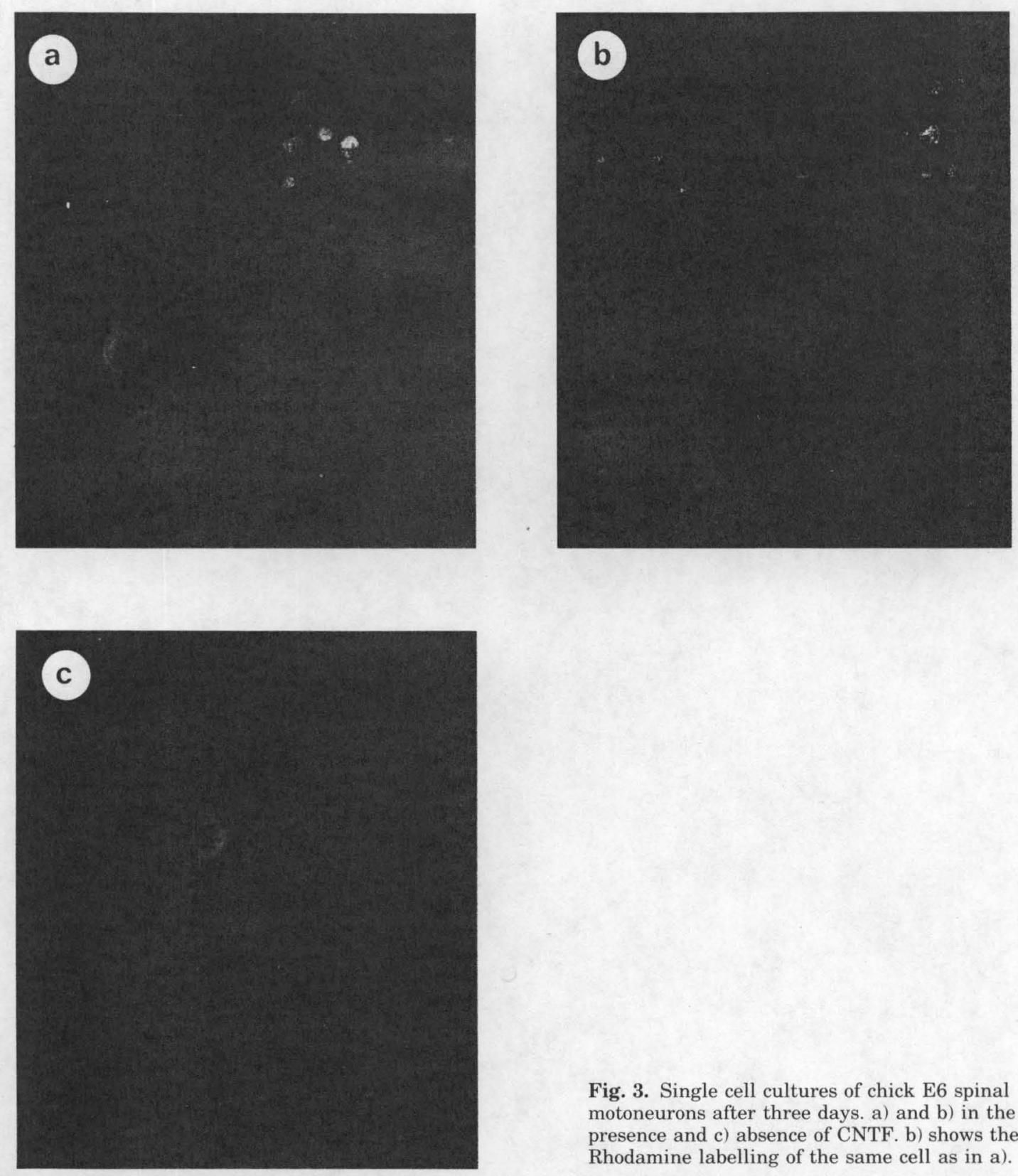

Fig. 3. Single cell cultures of chick E6 spinal motoneurons after three days. a) and b) in the presence and c) absence of CNTF. b) shows the Rhodamine labelling of the same cell as in a). 
Table 3. Survival of chick E6 spinal motoneurons in single cell cultures

\begin{tabular}{lcccc}
\hline & $\begin{array}{c}\text { Number of } \\
\text { cultures observed } \\
\text { with single } \\
\text { motoneuron }\end{array}$ & Survived & Died & \% Survival \\
\hline CNTF & 13 & 8 & 5 & 61 \\
CNTF+bFGF & 5 & 5 & - & 100 \\
None & 9 & - & 9 & 0
\end{tabular}

Cells were prepared as described previously by Arakawa et al. (1990), except that the final cell suspension was diluted and cells were cultured on Greiner 4 well dishes. Cultures with single cells were identified under phase contrast after $24 \mathrm{~h}$ in culture.

Indeed, aFGF has been shown to support the survival of chick ciliary neurons in vitro (Unsicker et al. 1987), to be present in large quantities in eye tissues and to bind to heparin with high affinity.

To exclude the possibility that the survival effect of CNTF on cultured chick E6 motoneurons is an indirect one, we studied their survival in single cell cultures. Motoneurons were retrogradely labelled by Rhodamine isothiocyanate, as described by Dohrmann et al. (1986). The neurons were then isolated and enriched by the method of Arakawa et al. (1990). In the presence of CNTF, 8 of 13 motoneurons in single cell cultures survived (Table 3). Addition of bFGF further increased the survival rates: in five single cell cultures all motoneurons survived. The motoneurons in single cell culture, identified by their Rhodamine fluorescence, extended long neurites on a laminin substrate. Control motoneurons died within two days in the absence of CNTF (Fig. 3). For the evaluation of the extent of survival, a time-point of three days after plating was chosen because, in the absence of survival factors, motoneurons are generally dead by that time. Beyond a three day culture period, the identification of motoneurons becomes increasingly difficult due to the fading fluorescence label.

\section{Survival effect of CNTF and bFGF on cultured E6 chick motoneurons depends on laminin as a substrate}

It is well established that molecules of the extra-cellular matrix, in particular laminin, potentiate the survival effects of neurotrophic molecules in vitro (Edgar and Thoenen, 1982; Edgar et al. 1984). Similarly, crude muscle extracts have been shown to contain soluble laminin or laminin-like molecules which potentiate the survival of cultured motoneurons in the presence of crude tissue extracts and fractionated muscle extracts (Dohrmann et al. 1986). We have re-investigated the function of laminin on CNTF and bFGF-mediated survival effects on cultured spinal motoneurons fro: . E6 chick embryos. Reducing the concentration of laminin used to coat culture dishes from 10 to $1 \mu \mathrm{g} \mathrm{ml}^{-1}$ led to a marked decrease in the survival rates of CNTF and bFGF (Table 4). In the absence of laminin very few neurons survived: $3.7 \%$ in the presence of CNTF, $8.9 \%$ in the presence of bFGF and $12.5 \%$ with the combination of both factors. These results are in agreement with earlier reports that laminin is necessary for maximal neurite outgrowth from cultured motoneurons (Calof and Reichardt, 1984) and that it potentiates the survival effect of muscle extracts on cultured motoneurons (Dohrmann et al. 1986). In comparison with the two-fold
Table 4. Survival of cultured chick E6 spinal motoneurons in the presence of $C N T F / b F G F$ is dependent on laminin as a culture substrate

\begin{tabular}{lcc}
\hline Factors present & $\begin{array}{c}\text { Amount of laminin } \\
\text { used for culture } \\
\text { dish coating }(\mu \mathrm{g})\end{array}$ & $\begin{array}{c}\text { Survival of motoneurons } \\
\text { after three days } \\
\text { in culture }(\%)\end{array}$ \\
\hline +CNTF & 10 & 55.4 \\
+bFGF & 10 & 44.4 \\
+CNTF+bFGF & 10 & 95.8 \\
None & 10 & 2.4 \\
+CNTF & 1 & 22.5 \\
+bFGF & 1 & 22.4 \\
+CNTF+bFGF & 1 & 53.3 \\
None & 1 & 0.0 \\
+CNTF & - & 3.7 \\
+bFGF & - & 8.9 \\
+CNTF+bFGF & - & 12.5 \\
None & - & 0.0
\end{tabular}

Motoneurons were prepared and cultured as described previously (Arakawa et al. 1990). Values are derived from one experiment and represent the mean of triplicate cultures.

increase in motoneuron survival by laminin in the presence of muscle extract, the potentiating effect of laminin on the survival effects of CNTF and/or bFGF was much higher, suggesting that the muscle extracts used might have contained suboptimal concentrations of laminin-like molecules.

\section{Discussion}

CNTF research has been blurred for a long time by the fact that survival effect on embryonic chick ciliary neurons in culture was the only parameter used for the identification and quantification of this molecule. There is now unambiguous evidence that molecules other that CNTF show similar survival effects in this assay; for instance aFGF, bFGF (Unsicker et al. 1987; Eckenstein et al. 1990) and purpurin (Schubert, 1986) support the survival of cultured chick ciliary neurons in a mannner which makes them indistinguishable from CNTF in this assay. The danger of using the ciliary neuron bioassay as an exclusive criterion is further demonstrated by the fact that CNTF immunoreactivity in the adult rat eye can only be detected in Schwann cells of innervating nerve fibres and neither CNTF mRNA nor CNTF protein are detectable in the rat retina (Stöckli et al. 1991). These recent data should be considered in the light of the original observations of Adler et al. (1979) who described high CNTF activity in these tissues based on the ciliary neuronal survival assay. Could it therefore be that the chick eye CNTF is unrelated to the adult rat sciatic nerve CNTF? This interpretation is supported by the observation that chick eye CNTF has been reported to bind to Heparin-Sepharose (BlochGallego et al. 1991), whereas in our own hands rat CNTF does not bind to Heparin-Sepharose in physiological phosphate buffer. Binding to Heparin-Sepharose is highly characteristic of aFGF, bFGF and other factors of the FGF gene family; rat and rabbit CNTF do not show sequence similarities to the FGF gene family. The interpretation that what initially has been characterized as CNTF in chick eye tissue could be more related to an FGF-like molecule rather than to CNTF is compatible with the following observation. The molecular weight of chick eye CNTF, as evaluated by SDS gel electrophoresis, seems to be significantly lower $\left(20.4 \times 10^{3} M_{\mathrm{r}}\right.$; Barbin et al. 1984) 
than that of rat $\left(24 \times 10^{3} M_{\mathrm{r}}\right.$; Manthorpe et al. 1986), rabbit (two bands of 22 and $24 \times 10^{3} M_{r}$; Lin et al. 1989) and adult chick sciatic nerve CNTF $\left(21.5 \times 10^{3} M_{\mathrm{r}}\right.$; Eckenstein et al. 1990). It has yet to be excluded that the molecule initially named chick eye CNTF is more related to aFGF than to sciatic nerve CNTF. Thus the final solution of this problem has to wait for the molecular characterization of chick CNTF and its recombinant production. Then it can be decided whether chick CNTF does indeed bind to Heparin-Sepharose, and therefore differs distinctly from mammalian CNTF, or whether the Heparin-Sepharose binding activity present in chick eye represents a molecule of the FGF gene family.

CNTF is not found in the target tissues of spinal motoneurons, sensory neurons and ciliary neurons in the rat. This, in addition to the finding that CNTF mRNA is not detectable in rat embryonic limbs, indicates that its physiological role concerning the survival of responsive neurons is distinctly different from that of known neurotrophic factors of the NGF gene family (Barde, 1989; Thoenen, 1991).

CNTF resembles aFGF and bFGF by the absence of a hydrophobic leader sequence and its non-release from transfected HeLa or COS cells (Stöckli et al. 1989; Lin et al. 1989). However, in comparison to bFGF, the distribution of CNTF in tissues of the adult rat is much more restricted. CNTF has so far only been found in Schwann cells in the peripheral nervous system and in a subpopulation of typeI astrocytes in the central nervous system, respectively (Stöckli et al. 1991). It can therefore be tentatively concluded that the function of CNTF is much more restricted to the nervous system than that of aFGF and bFGF. Our recent findings that CNTF rescues motoneurons from cell death after axotomy in newborn rats indicates that CNTF could act not only as a 'lesion factor' under pathophysiological conditions for motoneurons, but also for other neurons of the peripheral nervous system by its release from Schwann cells after injury. This would be in agreement with the relatively broad spectrum of biological activities of CNTF supporting all neurons projecting to the periphery investigated so far. However, the situation is complicated by the fact that there are species differences in the survival effects of CNTF in vitro, i.e. that, in contrast to chick embryonic neurons of nodose and sympathetic ganglia, CNTF has no survival effect on the corresponding neurons from newborn rats and mice, respectively (Table 1 ). It remains to be established whether these neurons acquire responsiveness to CNTF during their postnatal development, by analogy with chick dorsal root sensory neurons which are not supported by CNTF before E9-10 (Table 1).

In conclusion, although CNTF has a marked survival activity on embryonic motoneurons in culture, the absence of its expression in the target tissues of motoneurons, i.e. skeletal muscle cells, during the period of physiological motoneuron cell death excludes the possibility that CNTF is a physiological regulator of motoneuron survival, at least in rats. However, the observation that CNTF is expressed in large quantitites in the Schwann-cells of peripheral nerves, and that it prevents lesion-mediated degeneration of motoneurons in postnatal rats, is compatible with the assumption that CNTF might act as a 'lesion factor' under pathophysiological conditions, making it an interesting candidate for the treatment of degenerative diseases of motoneurons. It remains to be established whether its function as a lesion factor might also be extended to sensory and autonomic neurons, which, at least in chick, are supported by CNTF during lin periods of their development.

We thank A. M. Davies and Y.-A. Barde for their contribu of unpublished results to this publication; D. Edgar for he suggestions; and L. Bale for linguistic and editorial work o manuscript.

\section{References}

Adler, R., LANDA, K. B., Manthorpe, M. and Varon, S. (1979). Cholinergic neurotrophic factors: intraocular distribution of troph activity for ciliary neurons. Science 204, 1434-1436.

arakawa, Y., Sendtner, M. and Thoenen, H. (1990). Survival effe ciliary neurotrophic factor (CNTF) on chick embryonic motoneuro in culture: comparison with other neurotrophic factors and cytoki J. Neurosci. 10, 3507-3515.

Barbin, G., Manthorpe, M. and Varon, S. (1984). Purification of th chick eye ciliary neuronotrophic factor. J. Neurochem. 43, 1468-1

BARDE, Y.-A. (1989). Trophic factors and neuronal survival. Neuron 1525-1534

Bloch-Gallego, E., Huchet, M., El M'Hamdi, H., Xie, F.-K., Tana H. AND Henderson, C. E. (1991). Survival in vitro of motoneuron identified or purified by novel antibody-based methods is selective enhanced by muscle-derived factors. Development 11, 221-232

Calof, A. L. and Reichardt, L. F. (1984). Motoneurons purified by c sorting respond to two distinct activities in myotube-conditioned medium. Devl Biol. 106, 194-210.

Davies, A. M. AND Lindsay, R. M. (1985). The cranial sensory gangl in culture: differences in the response of placode-derived and neur crest-derived neurons to nerve growth factor. Devl Biol. 111, 62-72

Dohrmann, U., Edgar, D., Sendtner, M. and Thoenen, H. (1986). Muscle-derived factors that support survival and promote fiber outgrowth from embryonic chick spinal motor neurons in culture. 1 Biol. 118, 209-221.

Eckenstein, F. P., Esch, F., Holbert, T., Blacher, R. W. AND Nishi (1990). Purification and characterization of a trophic factor for embryonic peripheral neurons: comparison with fibroblast growth factors. Neuron 4, 623-631.

Edgar, D. AND Thoenen, H. (1982). Modulation of NGF-induced survival of chick sympathetic neurons by contact with a conditione medium factor bound to the culture substrate. Dev. Brain Res. 5 , 89-92.

Edgar, D., Timpl, R. And Thoenen, H. (1984). The heparin-binding domain of laminin is responsible for its effects on neurite outgrowt and neuronal survival. EMBO J. 3, 1463-1468.

Heumann, R., Korsching, S., Bandtlow, C. and Thoenen, H. (1987) Changes of nerve growth factor synthesis in nonneuronal cells in response to sciatic nerve transection. J. Cell Biol. 104, 1623-1631.

Hohn, A., Leibrock, J., Bailey, K. ANd Barde, Y.-A. (1990).

Identification and characterzation of a novel member of the nerve growth factor/brain-derived neurotrophic factor family. Nature 344, 339-341.

Holliday, M. AND Hamburger, V. (1975). Reductiun of the naturally occuring motor neuron loss by enlargement of the periphery. $J . c o m$ Neurol. 170, 311-320.

Landmesser, L. ANd Pilar, G. (1974). Synapse formation during embryogenesis on ganglion cells lacking a periphery. J. Physiol. (London) 241, 715-736.

Lin, L.-F., Mismer, D., Lile, J. D., Armes, L. G., Butler, E. T. III, Vannice, J. L. AND Collins, F. (1989). Purification, cloning, and expression of ciliary neurotrophic factor (CNTF). Science 246, 1023-1025.

Manthorpe, M., Skaper, S. D., Williams, L. R. And Varon, S. (1986) Purification of adult rat sciatic nerve ciliary neuronotrophic factor. Brain Res. 367, 282-286.

Masiakowski, P., LiU, H., RadzIEJEWSKI, C., LotTSPPeich, F. Oberthuer, W., Wong, V., Lindsay, R. M., Furth, M. E. AND Panayotatos, N. (1991). Recombinant human and rat ciliary neurotrophic factors. J. Neurochem. (in press).

OPPENHEIM, R. W. (1986). The absence of significant postnatal motoneuron death in the brachial and lumbar spinal cord of the rat J. comp. Neurol. 246, 281-286.

OPPENHEIM, R. W. (1989). The neurotrophic theory and naturally occurring motoneuron death. Trends Neurosci. 12, 252-255.

Oppenheim, R. W., Prevette, D., Qin-Wei, Y., Collins, F. AND MacDonald, J. (1991). Control of embryonic motoneuron survival in vivo by ciliary neurotrophic factor. Science 251, 1616-1618.

Pilar, G., Landmesser, L. and Burstein, L. (1980). Competition for survival among developing ciliary ganglion cells. J. Neurophysiol. 43 233-253.

SaAdat, S., Sendtner, M. and Rohrer, H. (1989). Ciliary neurotrophic 
factor induces cholinergic differentiation of rat sympathetic neurons in culture. J. Cell Biol. 108, 1807-1816.

Schmalbruch, H. (1984). Motoneuron death after sciatic nerve section in newborn rats. J. comp. Neurol. 224, 252-258.

Schubert, D., LACORBIERE, M. AND Esch, F. (1986). A chick neura retina adhesion and survival molecule is a retinol-binding protein. $J$. Cell Biol. 102, 2295-2301.

Sendtner, M., Kreutzberg, G. W. and Thoenen, H. (1990). Ciliary neurotrophic factor prevents the degeneration of motor neurons after axotomy. Nature $345,440-441$.

Stö́cku K. A., Liluen, L. E., Näher-Noe, M., Breitfeld, G., Hughes, R. A., Thoenen, H. And Sendtner, M. (1991). Regional distribution, developmental changes and cellular localization of CNTF mRNA and protein in the rat brain. J. Cell Biol. (in press).

Stöckl, K. A., Lottspeich, F., Sendtner, M., Masiakowski, P.,

Carroll, P., Götz, R., Lindholm, D. and Thoenen, H. (1989).
Molecular cloning, expression and regional distribution of rat ciliary neurotrophic factor. Nature 342, 920-923.

Tanaka, H. And Obata, K. (1984). Developmental changes in unique cell surface antigens of chick embryo spinal motoneurons and ganglion cells. Devl Biol. 106, 26-37.

Thoenen, H. (1991). The changing scene of neurotrophic factors. Trends Neurosci. 4, 165-170.

Unsicker, K., Reichert-Preibsch, H., Schmidt, R., Pettmann, B. Labourdette, G. and Sensenbrenner, M. (1987). Astroglial and fibroblast growth factors have neurotrophic functions for cultured peripheral and central nervous system neurons. Proc. natn. Acad. Sci. U.S.A. 84, 5459-5463.

Williams, L. R., Manthorpe, M., Barbin, G., Nieto-Sampedro, M., Cotman, C. W. AND VARON, S. (1984). High ciliary neuronotrophic specific activity in rat peripheral nerve. Int. J. Dev. Neurosci. 2 , 177-180. 